\title{
RINTISAN BISNIS KANTIN SEHAT PAUD KASIH IBU 1 DI DESA MOJOREJO KOTA WISATA BATU
}

\author{
Drs. Dicky Wisnu UR, M.M. \\ Fakultas Ekonomi Dan Bisnis \\ UMM
}

\author{
Fika Fitriasari, S.E., M.M. \\ Fakultas Ekonomi Dan Bisnis \\ UMM
}

\author{
Novi Puji Lestari, S.E., M.M. \\ Fakultas Ekonomi Dan Bisnis \\ UMM
}

\begin{abstract}
s
Sekolah Pendidikan Anak Usia Dini di Kota Batu sangat banyak namun sebagian dari sekolah mereka belum mempunyai unit bisnis yang bisa digunakan untuk melatih siswa bermain peran dan untuk tambahan penghasilan PAUD.Tujuan pengabdian ini adalah untuk merintis dan mengembangkan Bisnis Kantin Sehat PAUD Kasih Ibu di Desa Mojorejo Kota Wisata Batu. Perintisan usaha kantin sehat ini diharapkan dapat menjadi sumber pendapatan untuk tambahan dana operasional dan melatih para siswa dan gurunya di bidang kewirausahaan.

Metode Pelaksanaan yang digunakan dalam program pengabdian ini adalah pelatihan, pendampingan terhadap PAUD dan memberikan sosialisasi kepada guru tentang pentingnya rintisan bisnis untuk PAUD Kasih Ibu serta bisa membantu mewujudkan impian PAUD untuk membuat kantin. Rangkaian kegiatan nanti akan dimulai dari sosialisasi program sampai menghasilkan output yang diharapkan oleh pihak mitra dan tim pengabdian.
\end{abstract}

Kata Kunci: Bisnis, Kantin, Pendidikan

\section{PENDAHULUAN}

\section{A. Analisis Situasi}

Pendidikan Anak Usia Dini sangat penting dilaksanakan sebagai dasar bagi pembentukan kepribadian manusia secara utuh, yaitu untuk pembentukan karakter, budi pekerti luhur, cerdas, ceria, terampil dan bertakwa kepada Tuhan Yang Maha Esa. Pendidikan usia dini dapat dimulai di rumah atau dalam keluarga, perkembangan anak pada tahun-tahun pertama sangat penting dan akan menentukan kualitasnya di masa depan. Oleh karena itu, upaya-upaya pengembangan anak usia dini hendaknya dilakukan melalui belajar dan melalui bermain (learning through games).
Hal ini karena bermain merupakan kegiatan yang menyenangkan bagi anak melalui bermain anak memperoleh kesempatan untuk bereksplorasi (exploration), menemukan (finding), mengekspresikan perasaannya dan berkreasi (creation). Lembaga-lembaga PAUD di Indonesia memiliki pijakan yang sangat kuat berupa landasan yuridis, landasan filosofis, landasan religius, dan landasan keilmuan serta landasan empirik.

Pendidikan usia dini merupakan wahana pendidikan yang sangat fundamental dalam memberikan kerangka dasar terbentuk dan berkembangnya dasardasar pengetahuan, sikap dan keterampilan pada anak. Keberhasilan proses pendidikan pada masa dini tersebut menjadi dasar untuk proses pendidikan selanjutnya. Keberhasilan penyelenggaraan pendidikan anak usia dini, seperti : Kelompok Bermain, Taman Penitipan Anak, Satuan Padu Sejenis maupun taman kanak-kanak sangat tergantung pada sistem dan proses pendidikan yang dijalankan. (Nurbiana, 2009).

Desa Mojorejo merupakan salah satu desa yang terletak di kecamatan Junrejo Kota Wisata Batu. Di desa ini terdapat banyak pendidikan sekolah anak usia dini. Berdasarkan data di desa mojorejo terdapat 4 Sekolah pendidikan anak usia dini, yang salah satu diantaranya adalah PAUD Kasih Ibu 1. PAUD Kasih Ibu 1 kondisi manajemennya bisa dikatakan baik. Dengan jumlah tenaga pendidik 3 orang dan 1 orang Kepala Sekolah, dengan jumah siswa 23 siswa. Rinciannya adalah sbb : laki- Laki 17 siswa, dan perempuan 6 siswi

Dari Segi kemampuan keuangan PAUD ini memperoleh dana operasional dari siswa yang membayar iuran secara bulanan. Gaji pengelola juga berasal dari banyak siswa yang menjadi peserta didik dan sumbangan pendidikan dari wali murid. Untuk meningkatkan tambahan dana operasional dan menambah wawasan kewirausahaan bagi siswa- siswi PAUD ini mempunyai rencana untuk mendirikan kantin sehat yaitu kantin yang berbasis makanan sehat saja yang dijual. Namun rintisan usaha tersebut belum terwujud dikarenakan keterbatasan dana.

Berdasarkan gambaran umum di atas tim pengabdian dari Universitas Muhammadiyah Malang mempunyai rencana untuk membantu terwujudnya kantin sehat untuk PAUD Kasih Ibu 1. Perintisan usaha kantin sehat ini diharapkan dapat menjadi sumber pendapatan untuk tambahan dana operasional dan melatih para siswa dan gurunya di bidang kewirausahaan. Tim pengabdian dari Universitas Muhammadiyah Malang akan memberikan dukungan 


\section{STUDI KASUS INOVASI EKONOMI \\ Vol. 02 Issue 01, 2016 \\ ISSN : 2528-6269}

dan pendampingan demi terwujudnya kantin sehat ini. Adapun tahap-tahap dalam penyelesaian masalah dalam PAUD ini adalah sebagai berikut :

Gambar 1. Tahap-tahap penyelesian masalah PAUD Kasih ibu 1

\begin{tabular}{|c|c|c|}
\hline $\begin{array}{l}\text { Pertemuan } \\
\text { dengan Kepala } \\
\text { Sekolah untuk } \\
\text { menggali } \\
\text { permasalahan } \\
\text { yang ada }\end{array}$ & $\begin{array}{l}\text { Program } \\
\text { Pendamp } \\
\text { ingan } \\
\text { untuk } \\
\text { Kantin } \\
\text { Sehat }\end{array}$ & $\begin{array}{l}\text { Pelaksanaa } \\
\mathrm{n} \\
\text { Pengabdian } \\
\text { untuk } \\
\text { Pendampin } \\
\text { gan Kantin } \\
\text { Sehat }\end{array}$ \\
\hline
\end{tabular}

\section{B. Permasalahan Mitra}

Permasalahan utama yang dihadapi PAUD Kasih

Ibu 1 adalah sebagai berikut :

1. Keterbatasan kreativitas pengembangan produk kantin sehat PAUD Kasih Ibu 1.

2. Keterbatasan modal dalam mengembangkan usaha Kantin Sehat PAUD Kasih Ibu 1.

3. Kurangnya pengetahuan dan ketrampilan SDM dalam penyusunan manajemen Kantin Sehat serta Keterbatasan SDM dalam mengembangkan usaha Kantin Sehat PAUD Kasih Ibu 1.

\section{TARGET LUARAN}

Dalam Kegiatan Pengabdian masyarakat yang bekerjasama dengan PAUD Kasih Ibu 1, diharapkan dalam jangka panjang dapat memberikan nilai tambah ekonomi bagi Pengembangan Bisnis PAUD, sehingga dapat menjadi sumber pendapatan untuk tambahan dana operasional dan melatih para siswa dan gurunya di bidang kewirausahaan. Upaya untuk mencapai target luaran dilakukan melalui tahapan program yaitu sosialisasi, pelatihan dan pendampingan. Adapun target luaran pengabdian ini adalah sebagai berikut:

1. Pengembangan Kreatifitas pengembangan produk kantin sehat PAUD Kasih Ibu 1.

2. Manajemen Usaha kantin sehat PAUD Kasih Ibu 1 yang produktif dan profesional.

3. Produk kantin sehat berupa : aneka snack dan kue, bubur kacang hijau dan kacang merah, dan minuman (jus buah, susu, dan lainnya).

Peningkatan usaha yang dilaksanakan adalah dalam upaya untuk mewujudkan nilai tambah ekonomi yang dapat dihasilkan dalam kegiatan wirausaha kantin sehat, bila dapat dikembangkan secara terpadu dan profesional maka dapat menghasilkan nilai tambah ekonomi sebagai berikut.

\section{METODE PELAKSANAAN}

Metode Pelaksanaan yang digunakan dalam program pengabdian ini adalah pelatihan, pendampingan terhadap PAUD dan memberikan sosialisasi kepada guru tentang pentingnya rintisan bisnis untuk PAUD Kasih Ibu 1. Rangkaian kegiatan nanti akan dimulai dari sosialisasi program sampai menghasilkan output yang diharapkan oleh pihak mitra dan tim pengabdian. Permasalahan utama yang dihadapi PAUD Kasih Ibu 1 adalah keterbatasan modal, kurangnya pengetahuan dan ketrampilan dalam penyusunan manajemen Kantin Sehat serta mengembangkan usaha Kantin Sehat maka alternatif pemecahan masalah dapat dilakukan adalah sebagai berikut :

1. Memberikan penyuluhan dan pelatihan tentang pengembangan kreativitas produk Kantin Sehat untuk peningkatan kualitas produk.

2. Melakukan Pelatihan penyusunan manajemen usaha yang meliputi : pengelolaan produksi, pengelolaan sistem administrasi dan manajemen pemasaran.

3. Melakukan pendampingan kepada PAUD Kasih Ibu 1 dalam upaya penguatan usaha serta upaya untuk meningkatkan produksi dan kualitas produk.

4. Memberikan informasi tentang usaha kantin sehat kreatif yang menguntungkan dan perkembangan usaha kreatif yang telah maju.

\section{KELAYAKAN PENGUSUL}

Pelaksanaan kegiatan program pengabdian masyarakat ini diharapkan dapat menghasilkan luaran sesuai dengan tujuan, maka perlu SDM sesuai dengan tingkat kepakarannya. Kualifikasi tim pelaksana dan relevansi skill tim sangat mendukung dalam pelaksanaan Rintisan Bisnis Kantin Sehat PAUD Kasih Ibu 1. Tim terdiri dari ketua Drs. Dicky Wisnu Usdek, M.M adalah Dosen Manajemen Pemasaran Jasa yang cukup berpengalaman dalam pengabdian dan penelitian. Anggota tim Fika Fitriasari, SE.,MM adalah dosen manajemen yang berpengalaman dalam pengabdian dan penelitian dan aktif dalam berbagai kegiatan sosial masyarakat, dan Novi Puji Lestari SE,MM adalah dosen manajemen yang cukup berpengalaman dalam kewirausahaan, khususnya pada pemasaran online berbasis web serta berpengalaman dalam pengabdian dan penelitian.

\section{HASIL YANG DICAPAI}

\section{A. HASIL PELAKSANAAN KEGIATAN}

Kegiatan yang telah dilaksanakan pada PAUD Kasih Ibu 1 di Desa Mojorejo Kota Wisata Batu difokuskan untuk bisnis kantin sehat. Adapun hasil dari 


\section{STUDI KASUS INOVASI EKONOMI \\ Vol. 02 Issue 01, 2016 \\ ISSN : 2528-6269}

adalah sebagai berikut:

pengabdian yang telah kami lakukan

1. Penyuluhan dan pelatihan telah dilaksanakan untuk pengembangan kreativitas produk kantin

2. sehat PAUD Kasih Ibu 1 untuk peningkatan kualitas produk. Meningkatnya kreativitas bagi mitra usaha limbah konveksi akan meningkatkan pendapatan, sehingga usaha limbah konveksi bukan sekedar usaha sampingan tapi bisa menjadi usaha utama.

3. Pelatihan manajemen usaha kantin sehat yang telah dilakukan meliputi : a. Pengelolaan bagian personalia: penentuan tujuan, pengelompokan kerja, tugas dan tanggung jawab. b. Sistem administrasi: mencatat seluruh kegiatan usaha meliputi.

4. Pendampingan kepada PAUD Kasih Ibu 1 dilakukan dalam upaya penguatan usaha serta upaya untuk meningkatkan produksi dan kualitas produk. Pendampingan usaha secara berkelanjutan dilaksanakan untuk meningkatkan kemandirian usaha limbah konveksi.

\section{B. Hasil Kegiatan Pengelolaan Manajemen Usaha \\ Pengelolaan manajemen usaha yang lemah} banyak menyebabkan usaha kecil macet macet, dan ketika beranjak usaha tersebut besar akhirnya mengalami kegagalan. Dari permasalahan tersebut maka kami dari tim pengabdian masyarakat memberikan penyuluhan tentang mengelola manajemen usaha yang diawali dengan bagian personalia ,pengendalian produksi.administrasi dan pembukuan, menghitung laba perusahaan serta manajemen pemasarannya.

\section{Manajemen Sumber Daya Manusia}

Bisnis Kantin Sehat selalu terkait dengan pengembangan trend makanan terbaru, dimana selera masyarakat selalu berubah dan ter-update. Maka pengetahuan dan ketampilan mengembangkan bisnis kantin sehat sangat dibutuhkan oleh orang-orang yang bergerak dalam usaha ini.

\section{Manajemen Produksi}

Untuk mencapai efiensi, produktivitas dan mutu, dalam proses produksi usaha tersebut, maka perlu diperhatikan hal-hal sebagai berikut:
a. Penataan Ruang Kerja.
b. Pembelian Bahan.
c. Penjadwalan Pengerjaan Pesanan

\section{Sistem administrasi}

Banyak usaha kecil yang tidak membiasakan diri membuat catatan-catatan tentang kegiatankegiatan yang terjadi dalam usahanya. Tidak jarang terjadi bahwa janji atau pesanan terlupakan karena hanya mengandalkan ingatan,mereka cenderung menggunakan naluri dalam mengelola usahanya dengan menggunakan pengelolaan tradisional (ingatan dan naluri )

\section{RENCANA TAHAPAN SELANJUTNYA}

Adapun kelanjutan dari kegiatan pengabdian masyarakat ini dapat dilakukan dengan mengembangkan kegiatan dengan lebih memfokuskan bidang :
a. Manajemen pemasaran dengan menggunakan on line
b. Manajemen pengelolaan keuangan yang lebih professional

\section{KESIMPULAN DAN SARAN}

\section{A. KESIMPULAN}

Berdasarkan pada hasil pelaksanaan program IbM yang telah dilakukan maka dapat disimpulkan dan disarankan sebagai berikut :

1. Mitra kerja merasakan bahwa kegiatan pengabdian ini dapat meningkatkan kualitas produk

\section{B. SARAN}

Saran yang dapat kami sarankan sebagai berikut :

1. Perlunya pendampingan bagi mitra usaha PAUD Kasih Ibu 1 yang dilakukan secara berkelanjutan sehingga memberikan motivasi bagi mitra usaha lebih mandiri dan terus berkembang.

2. Kelanjutan dari kegiatan ini dapat dilakukan dengan mengusulkan program bermitra dengan kelompok yang mempunyai ketrampilan dalam mengembangkan usaha bisnis kantin sehat.

\section{DAFTAR PUSTAKA}

Dhieni, Nurbiana. 2009. Konsep Dasar Pendidikan Anak Usia Dini. Proyek Direktorat Tenaga Pendidik dan Tenaga Kependidikan Pendidikan Non Formal.

Soegoto, Eddy S. 2009. Entrepreneurship, Menjadi pebisnis ulung. Jakarta : Kompas Gramedia.

Untung, Budi. 2012. Hukum dan Etika Bisnis. Yogyakarta : CV Andi Offset.

http://paud.kemdikbud.go.id/article/detail/pendidikan_an ak_usia_dini-2 